\title{
COMMUTING PATTERNS IN RIGA AgGLOMERATION: EVIDENCE FROM A SURVEY ANALYSIS OF YOUTH
}

\author{
G̦IRTS BURGMANIS ${ }^{1}$ \\ University of Latvia (Latvia)
}

\begin{abstract}
In the last ten years the evident changes of settlement patterns through suburban growth near to capital city of Latvia occurred. Increase of distance between home and routine activity places as well as changes of public transport and rapid increase of car ownership initiated significant changes in commuting patterns of inhabitants living outside of Riga. Although the commuting from suburban area to Riga is recently broadly studied, however these researches focused primarily on able-bodied population leaving behind school-age children and young people. The aim of this study is to analyse commuting patterns of young people aged 12 to 17 moving from outskirts of Riga to school located in Riga. This study reveal commuting patterns in Riga agglomeration through wide analysis of spatial patterns of youth commuting, examination of motives and factors affecting transportation mode choice for school trips and commuting times. Findings of the research show existing correlation between location of young people's place of residence in terms of distance from core city and proportion of them commuting to Riga. Likewise several socio-demographic and socio-economic characteristics of young people have influence on school trip transportation mode choice.

KEY WORDS: youth, geographic mobility, commuting, transportation modes, Riga agglomeration.
\end{abstract}

JEL CODES: R32, J690, J130

DOI: http://dx.doi.org/10.15181/rfds.v14i3.860

\section{Introduction}

The society of 21 st century are characterised by increased mobility and ability to cover larger areas easier through highly developed transport infrastructure and availability of advanced and faster vehicles. The studies of the everyday movement of local residents, not only reflects the level of economic advantages and the development of social and transport infrastructure, but also links which exist among everyday activity places and help through diversity, intensity and nature of these links, demonstrate the extent to which local residents seek opportunities of work, education, health care, social and cultural amenities (Krišjāne, Bērziņš, 2009). In previous studies the commuting to work was used as an indicator to describe the people movement within Riga metropolitan area (Pierīga), process of suburbanization as well as development and changes of Riga agglomeration (Krišjāne et al., 2007; Krišjāne, Bērziṇš, 2011; Krišjāne, Bērziṇš, 2009, Krišjāne et al., 2012).

Although these studies show various aspects of commuting patterns such as profile of commuters, time and directions of commuting, these studies mostly ignore young people's everyday mobility. Therefore the commuting patterns within Riga agglomerations are not studied sufficiently losing experience of social group with high demands for mobility, but restricted by immaturity and dependency on adults as well as indirect effects of on-going urban transformation and socio-demographic processes including change of the place of residence due to on-going suburbanization, cut off public transport trips, automobilization and optimization of school network.

1 Girts Burgmanis - doctor, lecturer University of Latvia, Faculty of Geography and Earth Sciences. Scientific interests: human geography, urban geography, children and youth geography

E-mail: giirts_rhv@inbox.lv

Tel.: +37129341139 
The aim of the present paper is to analyse commuting patterns of young people aged 12 to 17 moving from outskirts of Riga to school located in Riga. This study has three main tasks. First, to reveal spatial patterns of youth commuting from Riga agglomeration towards Riga. Second, to consider motives and factors affecting youth transportation mode choice for school trips. Finally, to examine variations in commuting time by location of the place of residence and transportation mode used for school trip.

In order to gather the data for this study the author organized and managed survey of young people in eleven schools located and distributed in six residential neighbourhoods of Riga, Latvia.

1. Suburbanisation, optimization of school network and changes

in transportation behaviour

\subsection{Suburbanisation and development of Riga agglomeration}

The process of suburbanization similarly as in other Baltic countries (Tammaru, 2001) started in late 1960s and was based on simultaneous process of urbanization initiated by industrialisation and immigration mainly of Russian-speakers from the other Soviet Republics. In Soviet era the migration to suburban areas of major cities were determined by 1) the increasing food shortages throughout most of the socialist world; 2) soviet planning implications restraining spatial development in larger centres with more than 200000 inhabitants and restricting on in-migration to most large cities (Kule, 2009; Tammaru, 2007). Hence the part of the workers concentrated in rural areas near to large cities and in satellite towns. In period of two decades as in other East and Central Europe countries, a series of collective and state farms with high-quality residences and summer home villages emerged in areas around Riga, which provided workers with better homes and complementary agricultural products (Krišjane, Bērziņ̌š, 2009). Along with changes in settlement patterns the number of people living in Riga and the adjacent areas increased by $17 \%$ from 1045,000 in 1970 to 1227,000 by year 1989 (Filimonenko, 1991).

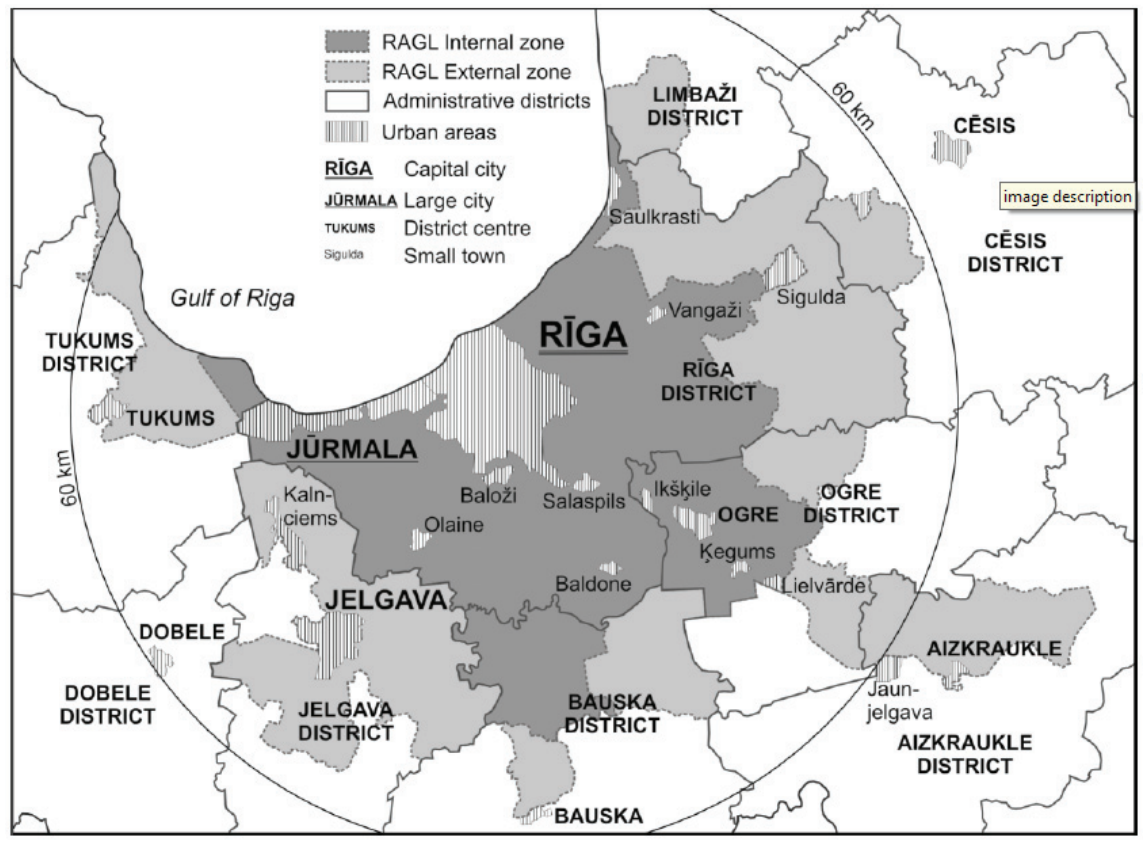

Figure 1. Spatial structure of Riga agglomeration

Source: Department of Human geography, University of Latvia, 2004

Rapid changes of settlement patterns and population growth near to Riga also encouraged necessity to identify the spatial structure and possible borders of this area for planning and research. In 1966 the Riga Suburban Zone Plan and later in 1980s a regional planning project defined Riga agglomeration as unit for 
further planning (Kūle, 2009; Krišjāne, Bērziṇš, 2009). The Rīga agglomeration was defined as "the area which is adjacent" to Rìga city (see Figure 1). Criteria for the delimitation of the boundaries of the Rìga agglomeration particularly focused on the intensity of labour migration at a radius of 60 to 70 kilometres with travel times of up to 1.5 hours and includes both urban and rural areas (Krišjāne, Bērziņš, 2009).

After the restoration of Latvia's independence in 1990s the suburbanization evolved under conditions of market economy including privatization, free price system and establishment of land and housing market. Such dramatic changes encouraged people of lower socio-economic status to leave the cities in order to find cheaper housing elsewhere, other people left the cities because the restitution policy enabled them to become landowners elsewhere (Markausa, 1997) as well as others returned to the suburban homes from which they had once departed in order to find jobs in the cities, especially when they became unemployed in the course of transition (Krišjāne, Bērziņš, 2011).

The process of suburbanisation started to develop more rapidly in the 2000s after joining the EU in 2004 along with the increase in individual wealth, supply of new housing and availability of mortgages (Bērziñš, Krišjāne, Krūzmētra, 2010). People who lived in Soviet-era apartment buildings were increasingly able to improve their living conditions by moving from these old or high priced apartments in city centre to cheaper or new-built dwellings in suburban areas. Upper- and middle-class households moved to suburban areas in search of a higher quality life and environment purchasing dwelling corresponding to their financial resources (Bērziņš, Krišjāne, 2008).

However new suburbanites often faced absence of appropriate social, cultural and recreational infrastructure within areas where new residences were located. This encouraged them to use the opportunities of education, medicine and recreation within towns and cities of agglomerations. For example these changes of settlement system within Riga and in Pierīga and displacement of residences outside of the city as well as lack of appropriate infrastructure stimulated rapid increase of distance between routined activity sites and commuting towards Rīga from suburban areas (Krišjāne, Bērziņš, 2009). Most of the former inhabitants of Riga from their residences on the outskirts for daily commuting to work frequently use private cars (Bērziñš, Krišjāne, Krūzmētra, 2010) without which it would be difficult to cover distances varying between few kilometres to more than 70 .

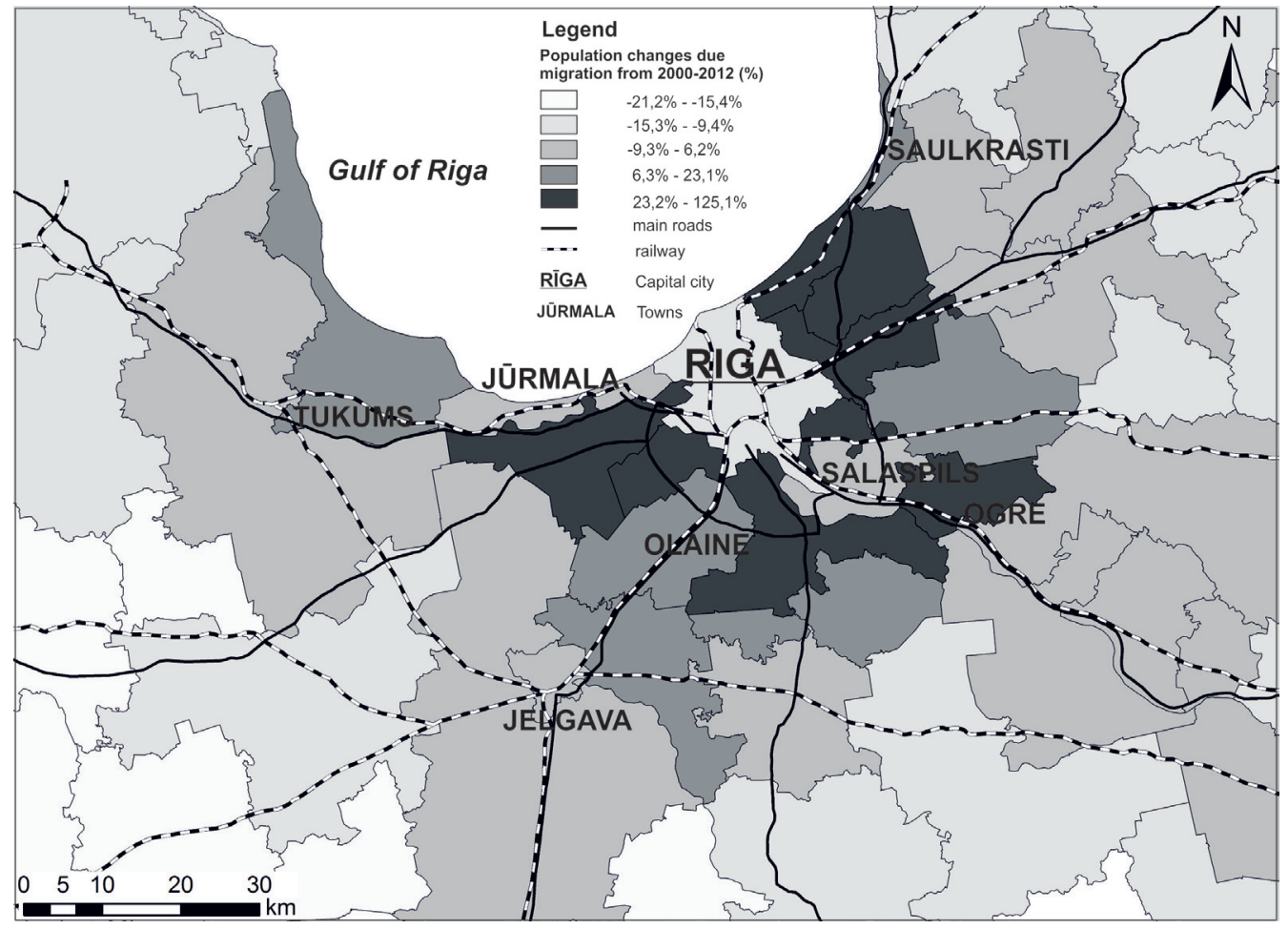

Figure 2. Population changes in municipalities of Riga agglomeration 2000-2012

Source: made by author according to data from CSB of Latvia 
Although in the last twenty years starting from 1991 the Riga agglomeration as Latvia experienced population decline due the return migration of Russians to Russia, emigration to the Western countries and negative natural population growth (Eglīte, Krišjāne, 2009), however the population of the Riga agglomeration has not decreased substantially since positive internal net migration has counterbalanced emigration losses. Net migration became positive in all municipalities around Riga ( 40 per cent population growth in the 2000s) in the 2000s as a result of suburbanisation (see Figure 2) and in 2007 the total population of the Riga agglomeration was 1151 112, including 429000 suburban residents (Krišjāne et al., 2007; Krišjāne, Bērziņš, 2011; Krišjāne et al., 2012). After administrative territorial reform in 2012 Riga agglomeration consists of 22 municipalities and 16 towns. The territorial structure of this area includes capital Riga as the central city and the internal and external zone of the agglomeration (Bērziņšs, Krišjāne, 2008). The two zones differ from one another by the nature of interaction between the zones and the capital city through intensity of daily commuting and density of population.

\subsection{Automobility and public transport system changes}

The economic and social changes experienced in Latvia in 1990s directly changed the conditions which previously guided the development of settlements. Critical changes took place in transport system significantly changing travel behaviour of inhabitants through excessive increase of private car ownership (see in Table 1). Such transformations had a several significant causes. The end of subsidized public transportation and growth of technical maintenance expenses determined dramatic increase of public transport prices in early 1990s in Latvia. The high public transport ticket prices along with relatively low petrol prices stimulated decline of public transport users and explosive car ownership and use. Privatisation of public transport sector determined that private enterprises were guided by interests of profit and decrease of passengers (also due negative population growth) was perceived as emergency to cut off public transport trips restricting commuters to easily access the work place or educational institution. Decline in public transport services made existing system of public transport deficient and encouraged acquiring and using a car for commuting. The high use of private car for commuting mainly characterizes Riga agglomeration (Krišjāne et al., 2007).

Table 1. The number of registered passenger cars per 1000 residents

\begin{tabular}{cccccccc}
\hline & Latvia & $\begin{array}{c}\text { Riga } \\
\text { agglomeration }\end{array}$ & Riga & Lithuania & Vilnius & Estonia & Tallinn \\
\hline $\mathbf{1 9 8 5}$ & 70 & & 83 & 96 & 73 & 114 & 116 \\
$\mathbf{1 9 9 0}$ & 136 & & 109 & 158 & 107 & 207 & 164 \\
$\mathbf{1 9 9 5}$ & 133 & 147 & 145 & 198 & 226 & 265 & 311 \\
$\mathbf{2 0 0 0}$ & 234 & 269 & 243 & 335 & 367 & 338 & 398 \\
$\mathbf{2 0 0 5}$ & 330 & 376 & 339 & 426 & 497 & 366 & 426 \\
$\mathbf{2 0 0 9}$ & 418 & 460 & 406 & 508 & 588 & 407 & 412 \\
$\mathbf{2 0 1 2}$ & 302 & 328 & 296 & 565 & 613 & 428 & 350 \\
Increase from & $\mathbf{2 2 2 \%}$ & $\mathbf{2 2 2 \%}$ & $\mathbf{2 7 2 \%}$ & $\mathbf{3 5 8 \%}$ & $\mathbf{5 7 3 \%}$ & $\mathbf{2 0 7 \%}$ & $\mathbf{2 1 3 \%}$ \\
$\mathbf{1 9 9 0}(\%)$ & & & & & & &
\end{tabular}

Source: own elaboration using data from various national transport agencies, The World Bank database (http://data. worldbank.org/indicator) and European Commission - Eurostat database (http://epp.eurostat.ec.europa.eu)

Emergence of market economics also resolved shortage of cars (Grava, 2007) and cost of car maintenance which previously was very expensive because for regular car usage the owner had to buy both petrol, and spare parts in black market (French, 1995). For example Riga, a city of close to a million people, had only ten places selling legally fuel in t 1980s (Grava, 2007). Hence it is also undeniable that in the late 1990s 
and in 2000s before economic crisis in 2008 the financial resources of households significantly raised and people become more prosperous which made private car purchase more affordable than in the Socialist era.

Although the number of private cars increased more than two decades in the last four years (from 2009) it started to decrease. Such decline of private car ownership is only partly associated with the economic crisis in 2008. Main cause for such changes was initiated by Road Traffic Safety Directorate of Latvia maintaining register of vehicles. The vehicles which were registered in other countries or were without roadworthiness test for last five years were excluded from register of vehicles.

\subsection{Population decline and optimization of school network}

After the regaining of independence in 1990 Latvia experienced continuous population decline due to negative natural population growth. Since 1991 the number of population decreased by 11000 people per year on average. Such demographic trends lead to significant decrease of the number of children and young people in school-age. For example, the number of school-age children in Riga and Riga agglomeration decreased by more than $35 \%$ from 2000 to 2012 (see in Figure 3).

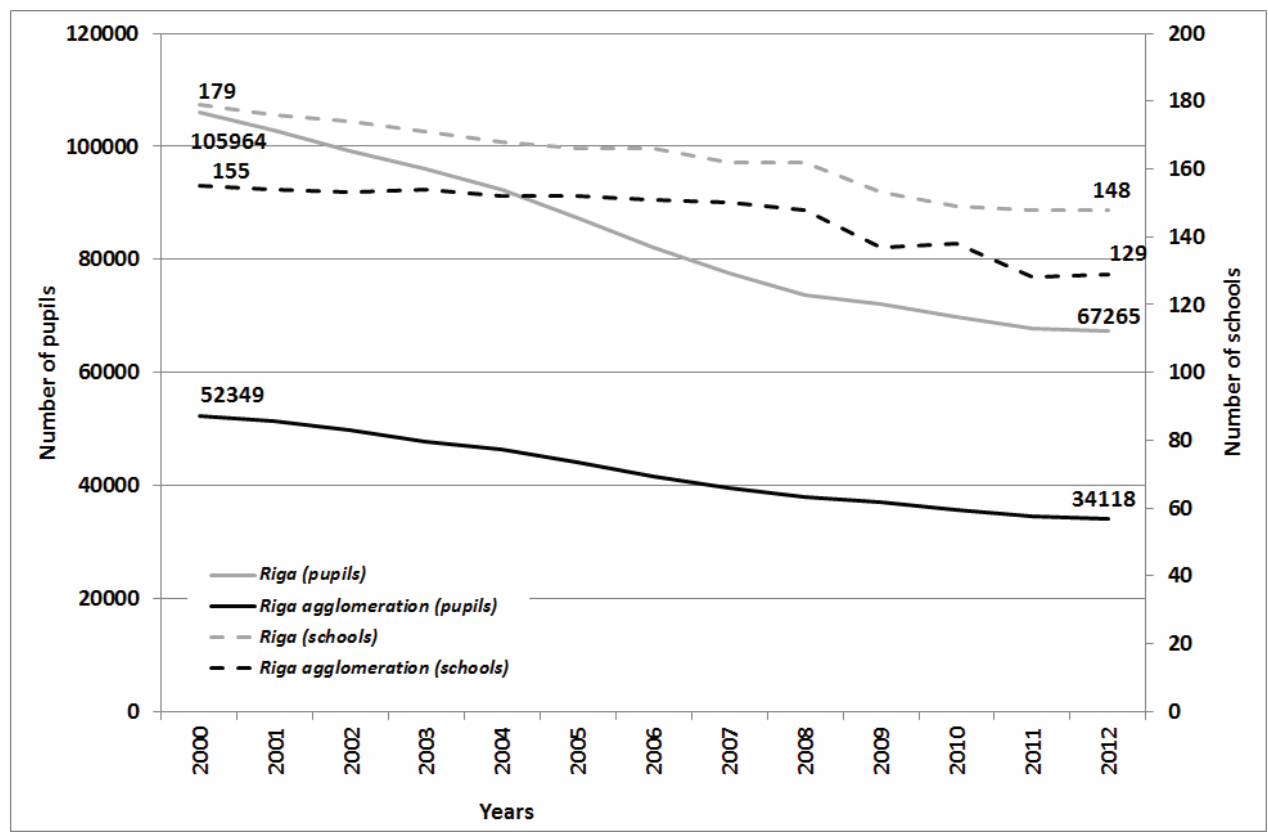

Figure 3. The number of pupils and schools in Riga and Riga agglomeration 2000-2012

Source: own elaboration according to data from CSB of Latvia

Such changes in the number of school-age children also have negative socio-economic effects. The existing model of school network maintained by the Ministry of Education and Science as well as local municipalities becomes ineffective and economically non-affordable. Therefore the revision and optimization of school network were initiated leading to closing and restructuration of prospectless schools. Immediate optimization of school network was forced by economic crisis in 2008. 150 schools (16\%) all over the country were closed in four years from 2008 to 2012. The vast majority of schools were closed in rural areas of Latvia forcing the school-age children to choose the schools located in cities or regional centres to precede their education.

Although the most of the schools were closed in rural areas similar trend was observable also in Riga and Riga agglomeration. Figure 3.shows that the number of schools both in Riga and Riga agglomeration decreased by $18 \%$ in period of twelve years (2000-2012).

Hence considering decline in number of schools and restricted accessibility of qualitative education in local areas parents and young people was forced to choose and attend the schools located further from home. 
This leads to observable changes in travel behaviour for school trips as well as to increase of flows of schoolage children from rural areas towards to cities and towns.

\section{Commuting patterns in Riga agglomeration}

Previous studies shows that in comparison to 1980s and 1990s daily commuting from the urban centres to rural areas decreased due to disappearance of job opportunities in suburban zone and in modern days the suburbanization is one of the main factors influencing increase of commuting flows from the suburbs to Riga (Krišjāne, Bērziņš, 2009). A total of 42 \% of those who migrated to the suburbs from Riga in last ten years became commuters because they continued working in the city (Krišjāne et al., 2012). The concentration of workforce towards Riga acknowledges that agglomeration is functionally monocentric where core is significant centre for industry, finance, education, entrepreneurship and transport.

In 2000s the largest share of commuters - more than $40 \%$ come from local municipalities adjacent to Rīga city as well as from towns and cities such as Baloži, Saulkrasti, Jūrmala, and Ogre located in agglomeration zone (Krišjāne, Bērziņš, 2009). Hence the percentage of commuters who travel from internal zone of Riga agglomeration to capital city are higher than proportion of commuters in external zone.

Although most of the commuters use public transport for travelling to work, however the increase of residents in municipalities near to Riga in last ten years also significantly extended traffic flows of private cars towards Riga. Approximately $60 \%$ of commuters use public transport as their main mode of transportation between home and work in Riga (Krišjāne et al., 2012) and 40 \% drive a car to get to work (Krišjāne et al., 2007). According to some studies the use of public transport is more pronounced for commuters without migration experience, but use of private car for commuters who migrated to suburbs (Krišjāne et al., 2012). Several studies examining young people travel behaviour and transportation mode choice in Riga agglomeration showed that the strongest effect on transportation mode choice for young people have only two factors - the family driving habits and travel distance (Burgmanis, 2012).

Previous studies on commuting times within Riga agglomerations shows that commuters who use public transport spend 13 minutes more travelling to work in Riga than other commuters (Krišjāne et al., 2012). However the commuting time depends also on location of the place of residence within agglomeration. Commuters who live in internal rural zone of Riga agglomeration spend 43 minutes in average for work trip. For other commuters who live in towns within internal zone (58 minutes) and in rural areas (70 minutes) and towns (62 minutes) of external zone the commuting times are even higher (Krišjāne, Bauls, 2011).

Largest socio-demographic groups of commuters from both internal and external zone of agglomeration are residents aged 20 to 44, Latvians, men, workers who earn average or high incomes (LVL 150-500; 200-700 EUR) and suburban inhabitants who hold university degrees (Krišjāne, Bērziņ̧̌s, 2009; Krišjāne et al., 2012).

\section{Youth's commuting behaviour and transportation mode choice}

Travelling by personal transport, public transport, and bicycle or on foot to the activity sites is the most significant activity daily performed by youths. A contemporary increase of the distance between activity spaces, growing prosperity and changes of intensity of urban life mostly in developed countries significantly increased the rates of car ownership and usage. The non-active and car oriented mode of mobility of families as 'consequences of complexity of modern life resulting in shortage of time' (Mackett, 2002) which directly affects children and young people's travel patterns through immaturity and dependency on adults. Parents chauffeuring their siblings to the activity sites reduce the opportunity for young people to travel independently and intervene in active interactions with environment indirectly restricting development of their social and spatial skills (Prezza et al., 2001; Rissotto, Tonucci, 2002; Rissotto, Giuliani, 2006). Passive transportation due to restrictedopportunity to access the most ordinary physical activity for human being - walking may also favour obesity (Cooper et al., 2003; Timperio et al., 2004). 
Some researchers have argued that distance between home and school is a critical factor which promotes children to walk or choose other transportation modes (McDonald, 2008, Nelson et al., 2009). Several studies emphasize that the choice of transportation mode for reaching a particular activity site is directly associated with youth's sex, age, family driving habits and previous experience of physical safety within the residential neighbourhood (Valentine, McKendrick, 1997; O'Brien et al., 2000; McDonald, 2008; 2010). Previous studies show that trips to and from school was used for analysing youth travel behaviour. This approach to represent youth commuting behaviour and patterns in Riga agglomeration is also used in this paper.

\section{Research Data and Methods}

\subsection{Data collection and questionnaire}

The data for this study was acquired from the survey, called "The Study of Children's Activities and Perception of Urban Environment" which was conducted from March 2010 to February 2012. The survey was performed in eleven schools located and distributed in six residential neighbourhoods of Riga, Latvia. The selection of eleven schools for surveying was made considering their location and the language of instruction and communication (i.e., six Latvian-language and five Russian-language schools were chosen). One teacher delivered and collected the questionnaires, which were designed to be completed within 40 minutes (length of lesson).

The questionnaire consisted of several parts and was designed to extensively study the commuting patterns of youth living in Riga agglomeration and attending the school in Riga. First part of questionnaire elicited general socio-demographic information about respondent and his/her household characteristics. There were questions asking respondents age, gender, current level of education, type of dwelling, duration of living in place of residence, location of place of residence. The second part of questionnaire examined travel behaviour of young people to most important daily activity sites such as to school, out-of-school formal activities, city centre and the consumed time for trip from home to school. The last set of questions dealt with family driving habits. This part of survey enquired how frequently parents use car weekly, does family have car and how often weekly parents chauffer children to school and other activity sites.

\subsection{Participants}

The questionnaires were distributed among pupils from primary school grades 6 to 9 and secondary school grades 10 to 11 . In total, 2975 students from 12 to 17 years were surveyed and filled the questionnaires. 2707 (91\%) questionnaires were accurately filled. Further to develop the study sample the students who completed the questionnaire but stated that they lived in Riga were eliminated from the analysis, which meant that only 339 (50\%) of the questionnaires were initially included; however, 324 (96\%) of these were accurately completed by the respondents and considered valid. Hence the total sample of study (n) was 324 respondents between the ages of 12 to 17 years.

\subsection{Data analysis}

Travel mode to school in spring and autumn was used as a dependent variable and consisted of two categories: car and public transport. Traveling time from home to school was also used as a dependent variable to analyse youth's commuting times. To study the transportation mode choice of youth for school trips the nine independent variables were used: sex, age, language of education, current education level, type of dwelling, parent's driving habits, duration of living in a place of residence, the location of place of residence, distance from home to school. For estimating travel distance from home to school the Google maps were used. The choices of independent variables were based on previous studies on young people travel behaviour and commuting patterns in Riga agglomeration. 
The Pearson chi square criteria test was used and calculated to convey whether there is a significant difference between the effect of two categorical independent variables (for example, sex) on a categorical dependent variable (transportation mode for school trips). The SPSS 18.0 for Windows software was used for the statistical data analysis. The cartographic software Arc Gis 9.3 was used to determine and describe the spatial commuting patterns of youth living in Riga agglomeration.

\section{Results and Discussion}

\subsection{Spatial Patterns of Youth Commuting}

Analysing spatial patterns of youth commuting in Riga agglomeration locations of young peoples' place of residence were used. The results show obvious connection between proportion of respondents attending school in Riga and location of their residential municipality within Riga agglomeration. Figure 4.confirms that most of the commuters (proportion of respondents is higher than $7 \%$ ) are going to Riga from adjacent municipalities (Babītes, Mārupes, Ķekavas, Stopiṇu, Garkalnes, Ādažu, Carnikvas) of Riga and Jūrmala $(19 \%)$.

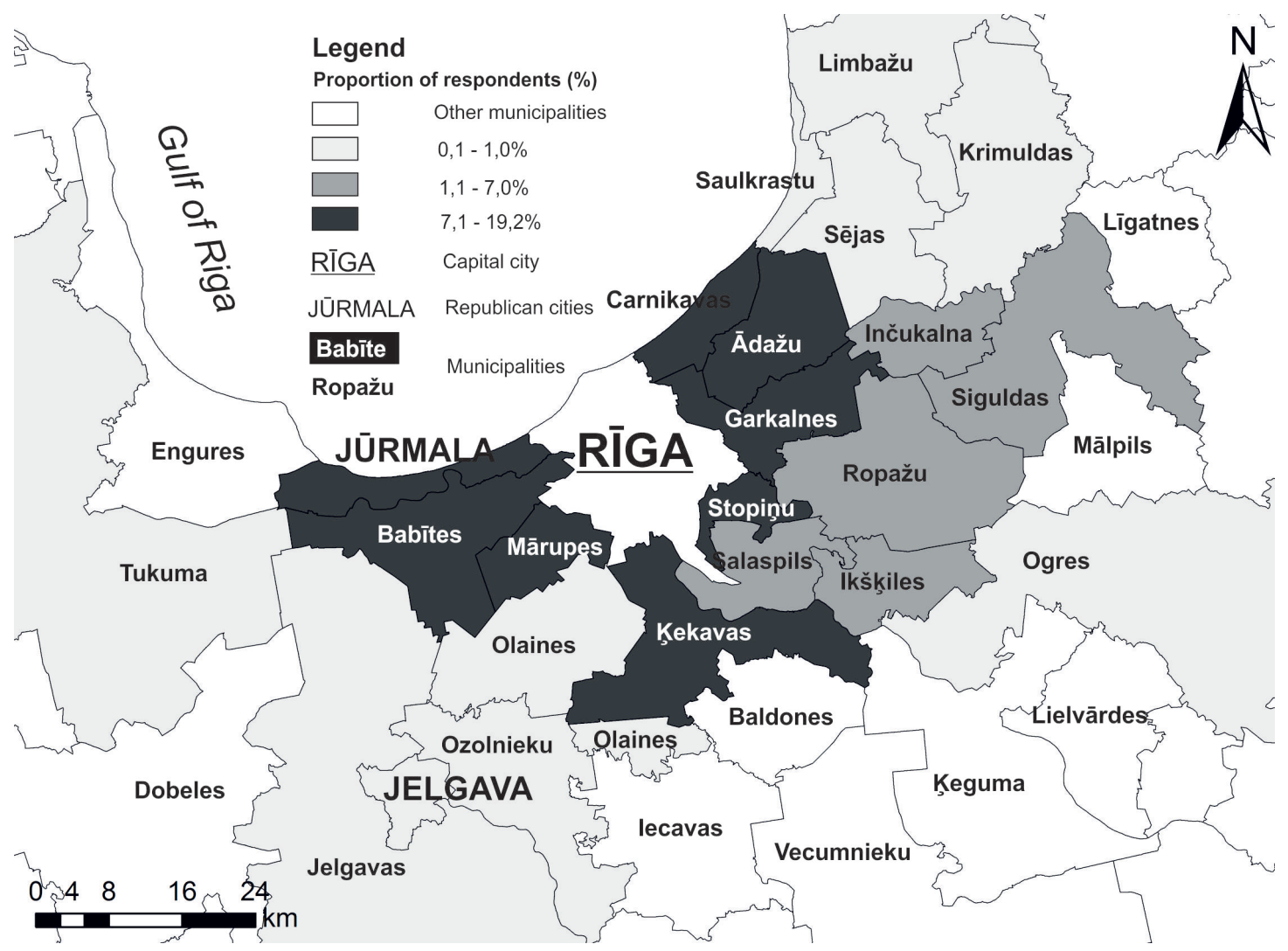

Figure 4. School trips from Riga agglomeration to Riga $(n=324)$

Source: made by author

Previous studies on spatial patterns of commuting in Riga agglomeration shows similar findings (Krišjane, Bērziñš, 2009) emphasizing that most of the commuters travel from internal zone of Riga agglomeration to Riga. Such findings have several obvious explanations. First, highly developed transport system including road network, public bus and train services mostly developed in the Socialist era and improved in Postsocialist era directly link Riga agglomeration internal zone with core city. Second, the frontier municipalities of Riga comparing to others are directly exposed to urban transformations and suburbanization. More frequently people desiring to change the place of residence and move from core city to suburban zone chose 
the place of residence which is located in more quiet and clean area but not far away from their workplace. Another reason to migrate to these municipalities is possibility to access appropriate social infrastructure (kindergarten, gym, swimming pool, etc.) comparing to municipalities located further from core city. Such behaviour leads to high growth of population in adjacent municipalities of Riga and is confirmed by previously discussed data from CSB of Latvia on domestic migration (see also Figure 2). Therefore it is logical that the commuting flows from municipalities like Babītes, Mārupes and etc. also are higher and the majority of young people from the sample of this study live in these municipalities.

The number of schools as component of social infrastructure within municipality without reference on its location may constrain also the flows of youth commuting. The Figure 4. shows that although several municipalities (proportion of respondents: Salaspils $-4.4 \%$, Olaines $-0.9 \%$ ) share border and has direct public transport connections both bus and train with Riga the number of commuters from these areas are less than from previously described. Within both municipalities there are average size towns - centres of municipalities - Salaspils with 18000 inhabitants and Olaine with 12000 inhabitants. In both towns there are two secondary schools, there for e young people living in these municipalities can access appropriate education and opportunities to enable them to develop their knowledge and skills near their homes and there is no need for them to travel longer distances to Riga.

\subsection{Commuting and Seasonality}

Examining transportation mode choice for school trips and effect of seasonality on such choice data in figure 5 shows that mostly young people are chauffeured to school by their parents. The private care for school trips is used nearly three times more frequently than public transport. These finding are not supported by previous studies on commuting from suburban areas of Riga to core city (Krišjāne, et al., 2012). In these studies where able-bodied population was sampled authors found that commuters use public transport as their main mode of transport for travelling between home and work. Results also show that seasonal changes do not encourage young people to change their transportation mode for school trips. Figure 5 shows that only small increase of car usage and decrease in public transport (3.6\%) are observable. Previous studies on youth's travel behaviour in Riga agglomeration shows similar findings (Burgmanis, 2012).

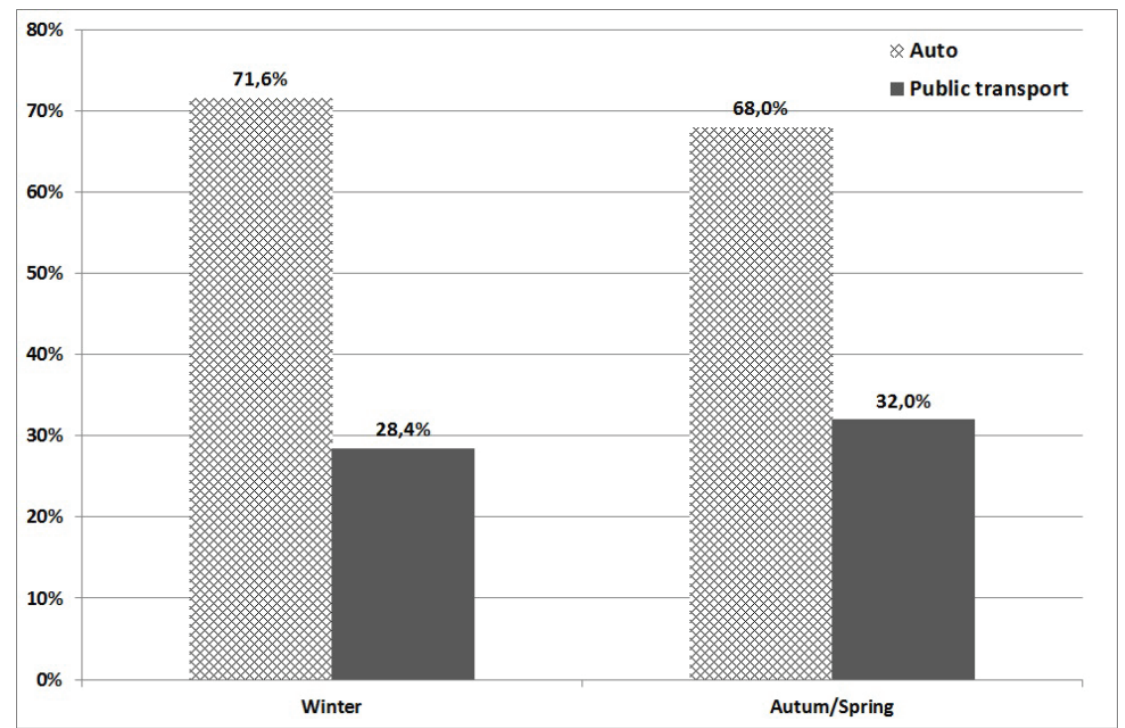

Figure 5. Transportation mode for school trips in spring/autumn and winter $(n=324)$

Source: made by author

The unweighted changes of transportation mode by various seasons could be explained with high usage of private cars by parents who are tended to choose the less time consuming and most comfortable transpor- 
tation mode to reach their work place without reference on season of the year. Similarly young people also choose the most comfortable way for the school trip if direction to parents' work place and school matches.

\subsection{Transportation Mode for School Trips}

To analyse factors influencing young people's choice of transportation mode for school trip to Riga categories of nine independent variables were compared (see Table 2). The Pearson chi-square test shows that the gender does not affect transportation mode choice. Both proportions of girls $(69.3 \%)$ and boys $(66.7 \%)$ who are chauffeured by parents or use public transport (respectively $30.7 \%$ and $33.3 \%$ ) for school trips are similar. Table 2 also shows that there are no differences between categories of two other independent variables. There are no statistically significant differences for transportation mode choice between young people learning in schools with Latvian and Russian as language of education as well as young people whose place of residence is located in rural areas of Riga agglomeration and in agglomeration cities or towns.

Results show that six of independent variables included in analysis affect transportation mode choice for school trips. There is evidence that older children more frequently choose to use public transport for commuting than younger children. These findings are consistent with previous researches focusing on independent mobility and emphasizing that spatial autonomy increases when children grow older and parents consider them competent enough for negotiating with danger in public space and public transport (O'Brien, 2000).

Table 2. Factors affecting transportation mode choice for school trips

\begin{tabular}{|c|c|c|c|c|c|c|c|}
\hline \multicolumn{2}{|c|}{ Factors } & \multirow{2}{*}{\begin{tabular}{|l} 
Auto \\
$66,7 \%$
\end{tabular}} & \multirow{2}{*}{$\begin{array}{c}\begin{array}{c}\text { Public } \\
\text { transport }\end{array} \\
33,3 \%\end{array}$} & \multirow{3}{*}{$\begin{array}{c}\boldsymbol{X}^{2} \\
0,259\end{array}$} & \multirow{3}{*}{$\frac{d f}{1}$} & \multicolumn{2}{|l|}{$p$} \\
\hline \multirow{2}{*}{ Sex } & Boys & & & & & 0611 & \\
\hline & Girls & $69,3 \%$ & $30,7 \%$ & & & 0,011 & \\
\hline \multirow{2}{*}{ Age } & $12-14$ & $75,6 \%$ & $24,4 \%$ & \multirow{2}{*}{9,098} & \multirow{2}{*}{1} & \multirow{2}{*}{0,003} & $* *$ \\
\hline & $15-16$ & $60,1 \%$ & $39,9 \%$ & & & & \\
\hline \multirow{2}{*}{ Language of education } & Latvian & $69,3 \%$ & $30,7 \%$ & \multirow{2}{*}{0,496} & \multirow{2}{*}{1} & \multirow{2}{*}{\multicolumn{2}{|c|}{0,481}} \\
\hline & Russian & $65,5 \%$ & $34,5 \%$ & & & & \\
\hline \multirow{2}{*}{ Education level } & Primary school & $72,9 \%$ & $27,1 \%$ & \multirow{2}{*}{10,729} & \multirow{2}{*}{1} & \multirow{2}{*}{0,001} & $* *$ \\
\hline & Secondary school & $53,6 \%$ & $46,4 \%$ & & & & N. \\
\hline \multirow{2}{*}{ Type of dwelling } & Apartament & $44,6 \%$ & $55,4 \%$ & \multirow{2}{*}{20,276} & \multirow{2}{*}{1} & \multirow{2}{*}{0,000} & $* *$ \\
\hline & Private house & $73,7 \%$ & $26,3 \%$ & & & & \\
\hline \multirow{2}{*}{ Parent's driving habits } & $<4$ times per week & $5,9 \%$ & $94,1 \%$ & \multirow{2}{*}{32,066} & \multirow{2}{*}{1} & \multirow{2}{*}{0,000} & $* *$ \\
\hline & $>3$ times per week & $71,6 \%$ & $28,4 \%$ & & & & 等 \\
\hline \multirow{2}{*}{$\begin{array}{l}\text { Duration of living in } \\
\text { a place of residence }\end{array}$} & $<5$ years & $75,2 \%$ & $24,8 \%$ & \multirow{2}{*}{7,634} & \multirow{2}{*}{1} & \multirow{2}{*}{0,006} & $* *$ \\
\hline & $>5$ years & $60,9 \%$ & $39,1 \%$ & & & & $w_{n}$ \\
\hline \multirow{2}{*}{ Place of residence } & Agglomeration rural areas & $70,2 \%$ & $29,8 \%$ & \multirow{2}{*}{2,17} & \multirow{2}{*}{1} & \multirow{2}{*}{0,141} & \\
\hline & Agglomeration cities/towns & $61,4 \%$ & $38,6 \%$ & & & & \\
\hline \multirow{2}{*}{ Distance } & $<25 \mathrm{~km}$ & $76,4 \%$ & $23,6 \%$ & 3004 & 1 & 0,048 & $*$ \\
\hline & $>25 \mathrm{~km}$ & $85,8 \%$ & $14,2 \%$ & 5,904 & 1 & 0,040 & \\
\hline
\end{tabular}

Source: made by author

Another factor which affects transportation mode choice is education level. Young people who attend secondary school more frequently choose the public transport for school trips. Although this factor is partly 
associated with children's age, however there can be also other explanation. In Latvia the largest movement between schools occur when young people graduate primary schools and choose the secondary schools where to continue their education. Furthermore in several municipalities that are included in Riga agglomeration only primary schools are situated. Alongside with other problems such as questionable quality of education and low accessibility of existing schools these circumstances encourage most of the young people after leaving primary school to exploit the educational opportunities provided by Riga. Hence it could be a free choice of young people or choice under pressure to choose school which can be located out of his/her local municipality or within other Riga neighbourhood. In particular cases the location of school may not coincide with direction to parents' workplace and such inconveniences stimulate to choose public transport for school trips.

At the residence level Table 2 shows that the children living in a private house more likely will use a car than walk to school. For example, young people living in private houses are chauffeured by parents to school nearly two times more frequently than children living in apartments. These findings imply that spatial patterns of youth commuting have significant effect on transportation mode choice. As found in previous studies private house as outcome of suburbanization is dominant building type in the nearest areas of Riga. Therefore author can make assumption that most of these young commuters who live in private houses come from municipalities located adjacent to Riga.

Family driving habits or frequency of car usage have the strong effect on car usage for daily commuting. $71 \%$ of young people whose parent use cars more than 3 times per week choose opportunity to go to school by car. Only $28 \%$ use public transport. Such results are not surprising because parents who work in Riga combine their trip to work with child >s chauffeuring to school. Young people who have changed their place of residence in last 5 five years are more likely to use car as transportation mode for school trips. These findings are partly consistent with results from previous studies on commuting of able-bodied people from suburban areas to Riga and indicate that private car use are more pronounced for commuters who migrated to suburbs (Krišjāne et al., 2012).

It is clear that distance from the place of residence to school also affect choice of transportation mode. Young people who live less than 25 kilometres from Riga choose car for school trips more frequently ( $76 \%$ ). These findings are not surprising because previous studies (Burgmanis, 2012) showed similar logic, i.e., that with increase of distance increases also proportion of car users and decrease the proportion of public transport users.

\subsection{Commuting Time}

The analysis of mean commuting times of young people shows that the majority ( $25 \%$ ) of them consume 35 minutes on average for school trips (see in Figure 6). The commuting times slightly changes and depends on used transportation mode. Young people who are chauffeured by parent to school by private car spend less time than those who travel to school by public transport. The highest proportions of private car users (27\%) spend 30 to 39 minutes for school trip. The largest proportion of public transport users lies between 20-49 minutes (42\%) and 60-69 minutes (17\%). Results showed in Figure 6 can be explained again by location of place of residence within Riga agglomeration and distance from home to school. Most of the young people come from adjacent municipalities of Riga and as mentioned in previous section are car users, therefore it is clear that their commuting times are significantly less than those who use public transport for school trip and live further from core city. 




Figure 6. Time spent (minutes) commuting to Riga

Source: made by author

To examine the effect of location of place of residence from another viewpoint author compared the commuting times of young people who live in Riga agglomeration rural areas and cities or towns. Like the young people who live in suburban rural areas $(67 \%)$ the residents of cities and towns (65\%) mostly spend from 20 to 49 minutes for school trips (see in Figure 6). Figure 7 confirms that mean times without reference on location of the place of residence in terms of type of settlement are similar. These findings are contrary to previous studies providing evidences that there are commuting time differences between commuters from rural areas and those who live in cities and towns (Krišjāne, Bauls, 2011).

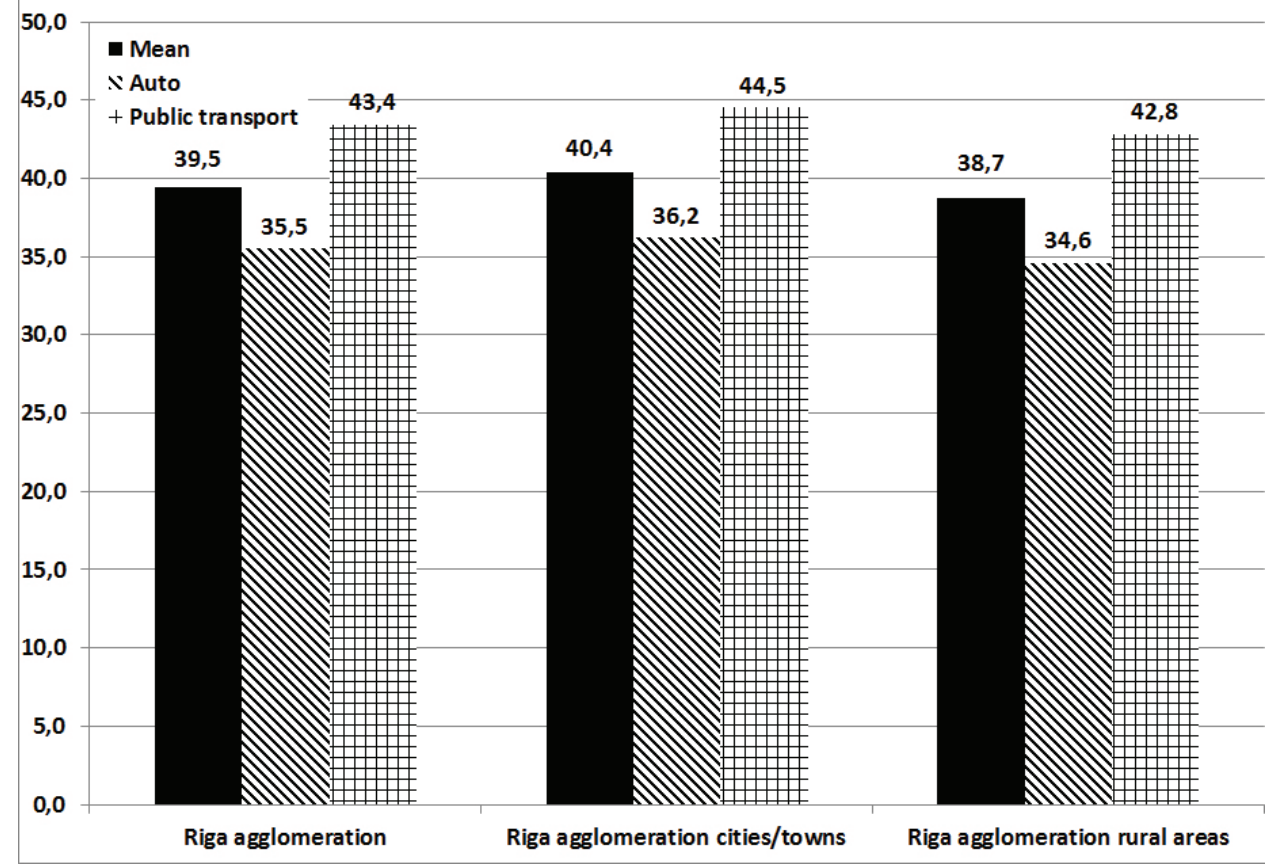

Figure 7. Mean commuting time to school

Source: made by author 
Figure 7 shows that mean commuting time for young people is 39 minutes. Comparing differences of mean commuting time between car and public transport users was found that young people who use car for school trips reach the destination about 8 minutes faster than public transport users. These findings are partly different with previous studies on commuting times of labour in Riga agglomeration. Firstly, the findings of Krišjāne and Bauls (2011) shows that mean time for commuters from home to Riga is nearly 51 minute. Secondly, difference between mean times of car and public transport users is somewhat higher - 13 minutes (Krišjāne et al., 2012) than shown in this study. Although such differences is difficult to explain, however author's assumptions considering that most of respondents use car for school trip is following: 1) previous studies concentrated on adults which more frequently used public transport; 2) the school mostly is situated in different place within Riga than parent's workplace; 3) the school is always the stop before parent's workplace. Therefore it is logical that the mean times of young commuters are less than adult's.

\section{Conclusions}

The results of this study are threefold. First, the spatial pattern of young commuters match with zoning model of Riga agglomeration developed by Department of Human geography (see in Figure 1) and depends on accessibility to transport infrastructure, distance from the place of residence to core city and positive population growth in last ten years in municipalities adjacent to Riga. Major flows of young commuters can be observed from municipalities which are located alongside the city Riga and matches with internal zone of Riga agglomeration. Second, socio-demographic characteristics of youth as well as on-going urban transformations can influence their choice of transportation mode. Results show that young people are more frequently chauffeured by parents to school if they are aged 12-14, attend primary school, and live in private house, migrated to suburbs less than five years ago and whose parents use care more than 3 days per week. Youth who live further than 25 kilometres from Riga more frequently use public transport for school trips. Third, this study strongly suggest that if the number of pupils still decline and optimization of school network in Riga agglomeration will continue the number of young public transport users commuting towards Riga will increase. Especially it is associated with optimization of secondary school network.

\section{References}

Berzins, M., Krisjane, Z., Kruzmetra, Z. (2010). An Emerging Pattern of Peri-Urban Growth in the PieRiga. Scientific papers University of Latvia: Earth and Environmental Sciences, Vol. 752, p. 253-267.

Bērziņ̌̌, M., Krišjāne, Z. (2008). Amenity migration in post-socialist metropolis: the case of Rīga agglomeration. Proceedings of the Latvian Academy of Sciences, Vol. 62B(1/2), p. 71-77.

Cooper, A. R., Page, A. S., Foster, L. J., Qahwaji, D. (2003). Commuting to school - are children who walk more physically active? American Journal of Preventive Medicine, Vol. 25, No. 4, p. 273-276.

French, R. A. (1995). Plans, Pragmatism and People: The Legacy of Soviet Planning for Today's Cities. London: UCL Press.

Grava, S. (2007). Urban transport in the Baltic republics. In: K. Stanilov (eds.). The Post-Socialist City: Urban Form and Space Transformations in Central and Eastern Europe after Socialism. Dordrecht: Springer.

Krišjāne, Z., Eglīte, P., Bauls A. et al. (2007). The geographical mobility of the labour force. Unpublished survey. Rìga: University of Latvia.

Krišjāne, Z., Bērziňš, M. (2009). Commuting and the deconcentration of the post-socialist urban population: the case of the Riga agglomeration. Folia Geographica, Vol. 14, p. 56-74.

Krišjāne, Z., Bērziņš, M. (2011). Post-socialist urban trends: New patterns and motivations for migration in the suburban areas of Riga, Latvia. Urban Studies, Vol. 49, No. 2, p. 289-306.

Kūle, L. (2009). Rural place identity reproduced by the Rīga hinterland spatial planning. Folia Geographica, Vol. 14, p. $38-55$.

Leetmaa, K., Tammaru, T. (2007). Destinations of suburbanisers in the Tallinn metropolitan area. Geografiska Annaler $B$, Vol. 89, No. 2, p. 127-146.

Mackett, R. (2002). Increasing car dependency of children: should we be worried. Proceedings of the Institution of Civil Engineers-Municipal Engineer, Vol. 15, p. 29-38. 
Markausa, I. M. (1997). Iekšèjāmigrācija Latvijā [Internal migration in Latvia]. Apcerējumi par Latvijas iedzīvotājiem [Studies of the Latvian population], Vol. 1, p. 34-64.

McDonald, N. C. (2008). Children's mode choice for the school trip: The role of distance and school location in walking to school. Transportation, Vol. 35, No. 1, p. 23-35.

McDonald, N. C., Deakin E., Aalborg A. E. (2010). Influence of the social environment on children's school travel. Preventive Medicine, Vol. 50, p. S65-S68.

Nelson, N. M., Foley, E., O'Gorman, D. J., Moyna, N. M., Woods, C. B. (2008). Active commuting to school: How far is too far? International Journal of Behavioral Nutrition and Physical Activity, Vol. 5, No. 1, p. 1-9.

O’Brien, M., Jones, D., Sloan D., Rustin, M. (2000). Children's Independent Spatial Mobility in the Urban Public Realm. Childhood, Vol. 7, No. 3, p. 257-277.

Prezza, M., Pilloni, S., Morabito, C., Sersante, C., Alparone, F. R., Giuliani, M. V. (2001). The influence of psychosocial and environmental factors on children's independent mobility and relationship to peer frequentation. Journal of Community and Applied Social Psychology, Vol. 11, No. 6, p. 435-450.

Rissotto, A., Giuliani, V. (2006). Learning neighbourhood environments: the loss of experience in a modern world. In: C. Spencer, M. Blades (eds.). Children and Their Environments. Cambridge: Cambridge University Press.

Rissotto, A., Tonucci, F. (2002). Freedom of Movment and Environmental Knowledge in Elimentary School Children. Journal of Environmental Psychology, Vol. 22, No. 1-2, p. 65-77.

Tammaru, T. (2001). Suburban growth and suburbanisation under central planning: The case of Soviet Estonia. Urban Studies, Vol. 38, No. 8, p. 1314-1357.

Timperio, A., Crawford D., Telford A., Salmon J. (2004).Perceptions about the local neighborhood and walking and cycling among children. Preventive Medicine, Vol. 38, No. 1, p. 39-47.

Valentine, G., McKendrick, J. (1997). Children's outdoor play: exploring parental concerns about children's safety and the changing nature of childhood. Geoforum, Vol. 28, No. 2, p. 219-235.

Филимоненко, Л. (1991). Проблемы развития Рижской огломерации: анализ проблем современного развития Рижской огломерации. Rīga: Latviskij NII Stroitelstva. Unpublished survey.

\title{
VAŽINĖJIMO RYGOS AGLOMERACIJOJE MODELIAI: JAUNIMO ANKETINÉS APKLAUSOS REZULTATAI
}

\author{
GirTs BURGMANIS \\ Latvijos universitetas (Latvija)
}

\section{Santrauka}

Per pastaruosius dešimt metų išryškèjo įsikūrimo modelio pokyčiai, lemiantys priemiesčių augimą aplink Latvijos sostinę. Padidèjęs atstumas tarp namų ir kasdienès veiklos vietų, pokyčiai viešojo transporto sistemoje ir didelis nuosavų automobilių skaičiaus nulemė aplink Rygą gyvenančių žmonių važinėjimo pokyčius. Nors ši tema pastaruoju metu išsamiai nagrinèta, vis dèlto mažai dèmesio skirta mokyklinio amžiaus vaikams ir jaunimui. Šio tyrimo tikslas - išanalizuoti jaunų žmonių (nuo 12 iki 17 metų), važiuojančių iš Rygos priemiesčių i mokyklas miesto centre, važinėjimo modelius. Atlikus tyrimą nustatyti važinèjimo Rygos aglomeracijoje modeliai, važiavimo trukmè, motyvai ir veiksniai, lemiantys transporto rūšies pasirinkimą. Tyrimo rezultatai atskleidè koreliaciją tarp jaunų žmonių gyvenamosios vietos atstumo nuo Rygos centro ir dalies jų važinèjimo ị Rygą. Nustatyta ir tam tikrų sociodemografinių bei socioekonominių jaunų žmonių charakteristikų įtaka transporto priemonių pasirinkimui.

PAGRINDINIAI ŽODŽIAI: jaunimas, mobilumas, važinèjimas, transporto priemonès, Rygos aglomeracija.

JEL KLASIFIKACIJA: R32, J690, J130 